\title{
Research on Cultivating and Practicing Core Socialist Values in the Context of Rule of Law
}

\author{
Bo Lei ${ }^{1, *}$ \\ ${ }^{I}$ School of Marxism, Beijing Jiaotong University, Beijing 100044, China \\ *Corresponding author.Email:03071538@163.com
}

\begin{abstract}
This paper discusses how to fully explore the legal factors and resources for the rule of law in the socialist core values, which can be greatly cultivated and established under the background of comprehensively ruling the country according to law. Based on the analysis of logical relationship and integrating point between the construction of socialist core values and comprehensively law -based governance, this paper puts forward five innovative promotion paths, they are, establishing the concept of legislative governance to strengthen the systematic cognition of socialist core values; developing and expanding the spirit of law to enhance the belief identity of socialist core values; maintaining legal authority to promote the institutionalization of socialist core values; Strengthening the education of rule of law to highlight the educational function of socialist core values, and using the thinking and practice of rule of law to achieve the effective goal of socialist core values. Keywords: the Core Socialist Values, the Rule of law, Cultivate, Practice
\end{abstract}

\section{INTRODUCTION}

In the system structure of the Core Socialist Values, the rule of law is one of its basic contents, a significant aspect of value orientation at the social level, and the core value pursuit of socialist society at the institutional level. Implement the Core Socialist Values into the concrete practice of governing the country according to law, run through all links of scientific legislation, strict law enforcement, fair justice and law-abiding by people from all walks of life, form an environment of socialist rule of law which is conducive to cultivating the Core Socialist Values, and strengthen the consciousness of people from all walks of life of practicing the Core Socialist Values with the concept and spirit of the rule of law. The rule of law is not only the inherent meaning of the Core Socialist Values, but also a powerful booster for cultivating and practicing the Core Socialist Values. Only when the Core Socialist Values are effectively integrated into the practice of the rule of law can people truly achieve the unity of ideological guidance and behavior guidance. Law is not only a social norm and regulation means, but also has its own internal value rationality for maintaining democracy and demonstrating justice. Therefore, it is a major innovation in the concept of rule of law construction to bring the rule of law into the Core Socialist Values from the level of social value orientation.

\section{ESTABLISH THE CONCEPT OF THE RULE OF LAW and STRENGTHEN THE SYSTEMATIC COGNITION OF THE CORE SOCIALIST VALUES}

As the basic content of the concept of socialist rule of law, the rule of law is also inevitably reflected in the concrete content and value pursuit of the Core Socialist Values. The rule of law is the core content of socialist rule of law and the fundamental guarantee for the realization of all value orientations of core values. The goals of economic prosperity, political democracy, advanced civilization and social harmony at the national level need to be continuously completed on the track of the rule of law. The pursuit of freedom, shared equality, fairness and justice at the social level needs to ultimately be based on the rule of law, which is the basic way of governing the country. The citizens' patriotism and moral code of conduct at the individual level, as well as the relief when the value norms are facing challenged and deviated, are also indispensable for the regulation of legal means. As the essential requirement of the socialist rule of law, law enforcement for the people should be guided by the Core Socialist Values, and the fundamental interests of the broad masses of people from all walks of life should be realized, maintained, and developed as the fundamental starting point and foothold of law enforcement. In the process of law enforcement, truly meet the essential requirements of the Core Socialist Values, and earnestly safeguard and protect the legitimate rights and interests of citizens. In law enforcement activities, the establishment of a socialist concept of the rule of law should be closely integrated with the reality of law enforcement work and team construction. 
The law enforcement entities should be educated and guided to firmly establish and adhere to the concept of governing the country according to law, effectively standardize the use of law enforcement powers, improve the credibility of law enforcement agencies in handling affairs according to law, firmly establish and adhere to the concept of law enforcement for the people, and strive to overcome the phenomenon of inaction in law enforcement. Fairness and justice is not only the value pursuit of the socialist concept of the rule of law, but also the connotation of the Core Socialist Values. It is a necessary way to realize the core value function whether it is the synchronization of legislative justice and judicial justice or the equal emphasis on substantive justice and procedural justice. Administrative law enforcement and judicial organs should correctly handle the relationship between entity and procedure, fairness and efficiency, and completely separate law enforcement and judicial power from related interests. The socialist harmonious society should adhere to the principles of legality, rationality, equality and justice, maintain social justice and promote mainstream values and positive energy by means of the rule of law. As an important mission of the rule of law, serving the overall situation is particularly significant at present, which is to serve the top priority of constructing the Core Socialist Values. The construction of the rule of law should be committed to the process of building a welloff society in an all-round way, strive to create a harmonious and stable social environment, a fair and efficient legal environment, and achieve the unity of legal effect, political effect and social effect. At present, constructing a society ruled by law is an extremely significant form of practice for practicing the concept of socialist rule of law and promoting the Core Socialist Values. The whole society should further emancipate the mind, innovate ideas and organically integrate the education of establishing the concept of the rule of law with the cultivation of the Core Socialist Values, and take social recognition and people's satisfaction as the final evaluation criteria. For one thing, the whole society should investigate and solve the existing problems from the level of ideological understanding and value concepts in the practice of implementing the concept of the rule of law. For another thing, the whole society should give full play to the guiding role of the Core Socialist Values education in the construction of a safe society and a society ruled by law.

\section{PROMOTE THE spirit OF LAW AND ENHANCE THE FAITH IDENTIFICATION OF THE CORE SOCIALIST VALUES}

The reason why a great quantity of laws in a country can form an internally coordinated legal system is that this series of legal systems and norms follow and embody the common legal spirit. Therefore, the socialist legal system with Chinese characteristics is a concrete interpretation and rule refinement of the socialist legal spirit. Only by establishing and improving the governance system of laws and rules, regulating subject behavior and social order, and ensuring national security, stability and sustainable development, can the core value orientation at the national, social and individual levels be truly realized. People oriented and rights supreme are not only the core elements of the spirit of law, but also the basic connotation of the Core Socialist Values. The spirit of law is people's unremitting pursuit of the value of social fairness and justice, and fairness and justice constitute the inherent essential attributes of the spirit of law. The spirit of law is the spiritual product of rational thinking about legal value. It needs to be carried out in the legal practice. Firstly, through the understanding of legal value and the operation of legal behavior, combined with the experience of the achievement of the rule of law to form and identify emotions. Secondly, an attitude towards legal faith is formed through rational cognition and value judgment. On this basis, it is externalized into legal behavior again. In this way, the legal spirit with legal faith as the core is formed. The cultivation of the Core Socialist Values is also based on practice, through pre-psychological feelings, and then internalize psychological cognition into conceptual form, and finally guide human behavior. The cultivation and practice of the Core Socialist Values presupposes specific scenarios and conditions for the common value spirit, legal faith, rational thinking and the behavior of the society ruled by law. In the meanwhile, legal spirit, legal faith and legal rationality provide unparalleled conceptual basis and rigid constraints for the internalization and externalization of the Core Socialist Values from other aspects of social ideology. By constructing a mature legal faith community among social groups and members, it is not only a key element to evaluate whether the spirit of law and its functions in a social superstructure are effectively embodied, but also to further enhance the faith identification of the Core Socialist Values. In short, it is a win-win process.

\section{MAINTAIN LEGAL AUTHORITY AND PROMOTE THE CONSTRUCTION OF A GUARANTEE MECHANISM FOR INSTITUTIONALIZING THE CORE SOCIALIST VALUES}

Legal authority focuses on the status and role of law in the process of state and social governance. In the various links of law operation, the authority of law mainly relies on its external coercive power and internal persuasive power. In contemporary China, firmly maintaining legal authority is of strategic significance for cultivating the Core Socialist Values and building the socialist country ruled by law. To use legal resources to promote the construction of the Core Socialist Values, it is necessary to integrate the content and requirements of the Core Socialist Values into the institutional design of legal norms, and also to implement legal authority into all fields of the overall layout framework of Socialism with Chinese Characteristics to 
form strong legal support and institutional supply. While strengthening the moral restraint and value guidance of social subjects, it constantly improves its legal concept and rule consciousness. On one hand, the behaviors and subjects that practice the Core Socialist Values shall be actively responded to from the legal level. On the other hand, the behaviors and subjects that deviate from the Core Socialist Values shall be strictly restricted and punished in accordance with the law. Only in this way can the process of cultivating and practicing the Core Socialist Values become a series of regulated processes where there are laws to follow and violations of the law should be prosecuted. The authority of the law comes from the people's inner support and sincere belief, while the regular role of legal authority provides a guarantee of the national will for the common value pursuit of the people's inner support and sincere belief. Legal authority not only depends on the state's coercive force to ensure the enactment and implementation of laws, but also depends on the institutional rationality of conscientious law itself. Firstly, to make legislation more scientific, which needs to fully reflect the aspirations of the broad masses of the people and fully reflect the connotation and requirements of the Core Socialist Values. Secondly, to strictly regulate and impartial law enforcement, which requires strict adherence to the legal system and legal spirit, as well as the maintenance of public order, good customs and value orientation in line with the requirements of the Core Socialist Values. Thirdly, to promote the judicial credibility, which promotes the inner conviction and active implementation of the Core Socialist Values among people from all walks of life. To be specific, solve the deep-seated contradictions and problems that affect judicial justice and restrict judicial ability, accelerate the construction of a fair, just, efficient and authoritative judicial system and mechanism, treat the demands of the people reasonably according to law, strive to make people feel fairness and justice in the judicial process, and resolutely prevent the harm of judicial unfairness to people's feelings and damage to their legitimate rights and interests. Judicial justice is the last line of defense to maintain social fairness and justice. Judicial justice not only forms the credibility of the rule of law among the people, enhances people's sense of trust in the law, but also enhances the concrete process of the effectiveness of the identification of the Core Socialist Values.

\section{STRENGTHEN EDUCATION IN THE RULE OF LAW AND HIGHLIGHT THE EDUCATIONAL FUNCTION OF THE CORE SOCIALIST VALUES}

The main task of publicity and education on the rule of law is to in-depth study and publicize various laws and regulations with the Constitution as the core, and to indepth study and publicize the Socialist Legal System with Chinese Characteristics, so that all citizens can broadly understand and master relevant legal knowledge. To realize the educational function of the Core Socialist Values, attention should be paid to the cultivation of legal knowledge, legal thinking and faith in the rule of law. In addition, through various forms and channels, promote the spirit of socialist rule of law, foster a culture of socialist rule of law, and make people fully believe in the law, consciously abide by the law and form the habit of being good at using the law to consider and solve problems. At present, the government education department has incorporated the education of the rule of law into the basic framework of the national education system and the establishment of spiritual civilization, and the publicity and education of the rule of law has also been regarded as an important indicator and evaluation content of the establishment of spiritual civilization. Departments concerned have to fully grasp the key stage of basic education, open and strengthen courses on the rule of law at all stages of basic education, launch education on basic knowledge of the rule of law, and constantly enhance the legal awareness of youngsters. To enable youngsters to understand the basic theory of modern rule of law and the basic principles of the Socialist Legal System with Chinese Characteristics, the legal system as well as the specific legal norms in civil, criminal, administrative, litigation and other fields, firstly, departments concerned should consciously follow the rules of youth growth and rule of law education. Secondly, departments concerned should adhere to the combination of rule education, habit formation and rule of law practice. Thirdly, departments concerned should adhere to the main channel of ideological and political education and actively develop the second classroom. In addition, departments concerned should give overall play to the roles of the society, schools and families, establish a systematic and complete three-dimensional legal education network, and improve the awareness and ability of youngsters to analyze and solve practical problems with legal knowledge. Chinese traditional legal thought is not only the cultural background and historical soil for the generation of the Core Socialist Values, but also provides ideological elements and cultural resources at the level of the rule of law for the Core Socialist Values. Therefore, to establish the faith in the rule of law in the whole society, departments concerned should vigorously promote Chinese traditional virtues to boost the construction of the culture of the rule of law, and further explore the ideological essence and moral essence of Chinese excellent traditional culture, especially the theoretical origins of many historical core values in Chinese legal history and legal ideology. Through the cultivation and edification of the culture of the rule of law at the spiritual and value level, people's faith in the rule of law is aroused, and a social fashion advocating the rule of law is formed. The rule of law education should further innovate the educational concept, pay equal attention to the popularization of legal knowledge and the cultivation of the concept of the rule of law, pay equal attention to the actual effect of the transformation of the concept of the rule of law and the cultivation of the spirit of the rule of law, and enhance the appeal and penetration of the publicity and education of the rule of law. 


\section{USE LEGAL THINKING MODE AND PRACTICAL ACTION TO ACHIEVE THE effective GOAL OF THE CORE SOCIALIST VALUES}

Being good at using legal thinking and actively participating in legal practice is the most direct manifestation of the internalization and externalization of the Core Socialist Values by social subjects under the dimension of the rule of law. It is also the effective goal of cultivating and promoting the Core Socialist Values. The construction of the rule of law requires the concept of the rule of law to be recognized from overall cognition to individual identity, from subjective thinking to objective practice, and transform the spirit of the rule of law from conceptual principles to behavioral methods, truly permeate the hearts of people from all walks of life, and construct consensus by means of the rule of law. The socialist rule of law thinking and practice is the most accurate interpretation and recognition by people from all walks of life of the inherent concept and spirit of the Socialist Legal System with Chinese Characteristics. The mode of thinking of law is a mode of thinking cultivated by subtle training in legal practice. Only by participating in legal practice activities and applying legal knowledge and methods to analyze and solve legal problems in legal practice can people shape good legal emotions, attitudes and values, and form conscious legal thinking and living habits. With the deepening of the cultivation and practice of the Core Socialist Values, the scope of the adjustment of law to social life is becoming more and more extensive, and more legal means are needed to solve the social disputes and conflicts of interest faced by people from all walks of life, which not only puts forward new and higher requirements for the application of legal thinking and practice, but also provides a promising broad space for the penetration of the Core Socialist Values into the hearts of people from all walks of life.

\section{CONCLUSION}

At present, comprehensively advancing the rule of law, whether it is a major change in the national governance system and governance capacity, or the external transformation of the concept of the rule of law to concrete social behavior, means to deeply cultivate the theory and practice of the rule of law from the perspective of the Core Socialist Values. As the core value orientation at the social level, the concept of socialist rule of law focuses on scientifically answering the major theoretical and practical questions of "what a socialist country under the rule of law is" and "how to build a country under the rule of law", which itself is an unavoidable and necessary question to cultivate and practice the Core Socialist Values. The construction of the Core Socialist Values and the comprehensive promotion of the rule of law are a systematic project that complements and promotes each other. The construction of the Core Socialist Values is the essential requirement of socialist ideology, and the comprehensive promotion of the rule of law is an important manifestation of the reform and development of socialist political civilization, and it is the acceleration of the modernization of the national governance system and governance capacity in the dimension of the rule of law. Therefore, giving full play to the value resources and social functions of the construction of the rule of law is of great significance for the use of the Core Socialist Values to form a strong common value pursuit in the whole society and to realize the great rejuvenation of the Chinese nation.

\section{REFERENCES}

[1]Wang Liming, Zhang Meichang. The Basic Issues concerning the Construction of the Rule of Law in China in the New Era[J]. Social Sciences in China, 2020(01):21-36. (In English)

[2]Zhang Xiaoyan. Jurisdiction of Law with Perspectives of Rule of Law, Rule of Virtue and Autonomy[J]. Fudan Journal(Social Sciences Edition), 2020,62(01):1-12. (In Chinese)

[3]LI Lin. Six Dimensions of Innovative Development of Chinese Theory of Rule of Law in a New Era[J]. Chinese Journal of Law, 2019,41(04):3-20. (In Chinese)

[4]SUN De-chao, ZHOU Yuan-yuan. On the Process Mechanism of Absorbing Socialist Core Values in the Construction of Rule of Law in China[J]. Theoretical Investigation, 2018,(06):30-36. (In Chinese).

[5]Zhang Di. "Family Civilization": The Important Points of Cultivate and Practice the Socialist Core Values [J]. Henan Social Sciences, 2017,(10):53-57. (In Chinese).

[6]Gong Pixiang, ed. The Modernization of the Rule of Law in Contemporary China [M]. Law Press · China, 2017:70-72. (In Chinese) 